
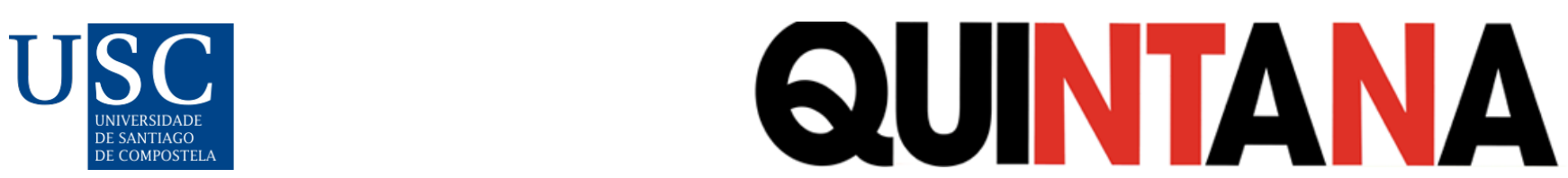

Quintana: revista do Departamento de Historia da Arte, (20), 2021. ISSN-e: 2340-0005

https://doi.org/10.15304/quintana.20.7464

Reseñas

\title{
Reforma y tradición en el románico gallego. Los ejemplos de Rebordáns y Mondoñedo. Javier Castiñeiras López, Universidad de León-Instituto de Estudios Medievales, León, 2020. 419 págs. ISBN 978-84-9773-627-5
}

Francisco de Asís García García ${ }^{1}$ iD

${ }^{1}$ Universidad Autónoma de Madrid, España

Desde que Meyer Schapiro publicara en 1939 su célebre trabajo sobre el claustro de Silos, la evaluación de las creaciones artísticas hispanas de finales del siglo XI e inicios de la siguiente centuria ha recurrido con frecuencia al binomio de la tradición y la vanguardia como clave de análisis. Caracterizar el paisaje monumental y la cultura visual de estas décadas desde la óptica del cambio se ha revelado provechoso, y ha permitido señalar afinidades y, también, divergencias respecto a otros fenómenos abordados desde modelos explicativos similares. La renovación litúrgica y monástica experimentada en los territorios peninsulares se cuenta entre ellos, y se ha entrelazado asiduamente en las discusiones con el hecho artístico, pese a que los ritmos desiguales y los vaivenes propios de estos procesos inviten a descartar correlaciones nítidas. La reforma comúnmente denominada "gregoriana" se ha reivindicado como otro ingrediente esencial del panorama eclesiástico y político entre los siglos XI y XII. En las últimas décadas, la historiografía artística ha procurado entender a partir de estas experiencias reformadoras cuestiones tan relevantes como la definición de los espacios y de las formas arquitectónicas, la emergencia a gran escala de la escultura monumental, su entronque antiquizante, o la creación de programas destinados a la corrección de costumbres o a la exaltación del poder eclesiástico. El éxito inicial de esta propuesta interpretativa, que ya acarrea una larga trayectoria, se ha visto posteriormente matizado y sigue siendo objeto de revisión, tratando de examinar desde lo particular la validez de interpretaciones globales. En esta encrucijada se sitúa la obra aquí reseñada, que sitúa la mira en el extremo noroccidental hispano en el entorno de 1100.

Hablar de arte y reforma eclesiástica en el ámbito gallego de estas décadas conduce inevitablemente a centrar la atención en la catedral de Santiago y a recordar, en especial, los valiosos estudios que desde los años noventa le viene dedicando Manuel A. Castiñeiras; autor que también se ha interesado por enclaves artísticos próximos desde esta misma perspectiva, y en particular por uno de los tratados en esta monografía, San Martiño de Mondoñedo. La ambición artística que revelan los proyectos compostelanos, sus conexiones con otros centros de creación europeos y el aval de las fuentes han encumbrado al santuario apostólico dentro las cartografías del "arte de la reforma". Una de las virtudes de la presente publicación estriba en la consideración dada a otras fábricas cuyas experiencias artísticas se habían visto desatendidas ante la merecida 
notoriedad de la catedral de Santiago, con la que discurrieron en paralelo. Su análisis permite no solo devolverles protagonismo, sino también -y lo cual es más fructífero- evaluar desde contextos particulares la validez de paradigmas de largo alcance, construidos a partir de la decantación de hitos significativos. Tal fue la tarea acometida por Javier Castiñeiras López en su tesis doctoral, de la que deriva este libro. Con él se incorpora a una ilustre nómina de investigadores -en su mayoría gallegos y vinculados de algún modo a la Universidade de Santiago de Compostela- que desde el último cuarto del siglo XX han esclarecido el desarrollo artístico del territorio galaico en época románica.

La monografía se articula en torno a dos ejemplos de diversa categoría y acogida historiográfica: San Bartolomé de Rebordáns y el ya citado San Martiño de Mondoñedo. Situados en diócesis contiguas a la poderosa Compostela, ambos templos sirvieron de pasajera sede episcopal en sus demarcaciones respectivas y acusaron la impronta monástica -manifiesta en Rebordáns- antes de asociarse a comunidades de canónigos agustinos. A su vez, son acreedores de una compleja fortuna material que dificulta el trazado de su historia constructiva y suma incógnitas potenciadas por la escasa documentación conservada. Por ello, abordar el estudio de estos templos supone una ardua tarea, a la par que necesaria. A lo largo de las 340 páginas de texto su autor desgrana procesos históricos, biografías arquitectónicas y lecturas iconográficas a fin de responder a una cuestión enunciada al término de la introducción: “ison las campañas artísticas de San Martiño de Mondoñedo y San Bartolomé de Rebordáns un ejemplo de lo que se ha venido llamando un 'arte reformado' o, por el contrario, estamos ante muestras de una cultura conservadora y refractaria a los cambios?".

Para perfilar el horizonte de su pesquisa, el autor atiende en un primer bloque a algunos de los síntomas más evidentes de los movimientos reformadores que se sucedieron en la segunda mitad del siglo XI en el noroccidente ibérico: la actividad conciliar, la reconfiguración del mapa diocesano y las mutaciones litúrgicas. Dichos compases ponen de relieve dinámicas propias conjugadas con la acción romana; esta se hizo más palpable conforme se acercaba el cambio de siglo, sin llegar a ser agente único de cambios ni renovadora absoluta de la realidad eclesiástica peninsular. Por ello son comprensibles las cautelas con las que ha de abordarse la relación entre reforma gregoriana y expresión artística, asumida por el autor como punto de partida para indagar en los ejemplos acotados sin obviar las flaquezas metodológicas que presenta el relato del "arte gregoriano".

Este marco inicial concluye con una síntesis de la historia constructiva de Rebordáns y San Martiño -necesariamente extendida hasta las intervenciones contemporáneas- que quizá habría tenido mejor encaje en el siguiente bloque, dedicado al análisis material de las fábricas y su configuración espacial. En ambos casos se revisa concienzudamente lo dicho hasta la fecha, valorando con diverso resultado los posibles precedentes altomedievales consignados por una parte de la historiografía. En Mondoñedo el examen constructivo, unido a reveladoras analíticas, invita a descartar el pie forzado de anteriores edificaciones y corrobora tres fases que se suceden entre los años setenta del siglo XI y el segundo cuarto de la siguiente centuria, en las que confluyen léxicos propios del primer románico con otros afines a las corrientes languedocianas del norte peninsular. La espacialidad de Rebordáns acusa mayores deudas con la tradición altomedieval que la iglesia mindoniense, sin que por ello deba adelantarse su erección antes de la década de 1070.

El autor es consciente de los inconvenientes que supone escindir del análisis constructivo el complemento escultórico, protagonista del tercer bloque del libro con el estudio pormenorizado de los repertorios ornamentales y motivos figurados de los dos templos hasta inicios del siglo XII. Estos ya habían sido vinculados en razón de su definición formal y de las coincidencias 
temáticas que presentan. Se ponderan aquí las propuestas arrojadas por trabajos precedentes, profundizando en las fuentes de las imágenes, su tradición visual y los matices que el examen de la gestualidad puede proporcionar para su valoración semántica. Penitencia y escatología son las líneas maestras de los mermados discursos que se despliegan en los sectores orientales de ambos templos, preferentemente dirigidos al clero en opinión de Javier Castiñeiras, quien reconoce tanto débitos con la tradición ilustrativa altomedieval como sintonías con modelos coetáneos. Destaca, en este sentido, su apreciación de las adaptaciones icónicas realizadas en Rebordáns, quizá obviadas ante la rudeza estilística de sus capiteles, así como la detenida discusión sobre el antipendio de Mondoñedo, función por la que se inclina en detrimento del alternativo uso como retablo de esta singular pieza. Las conexiones del frontal con los capiteles del templo son señaladas en una lectura conjunta que incide en la dimensión sacramental de las imágenes.

El autor hace gala de prudencia en sus juicios, abiertos a los márgenes interpretativos que su objeto de estudio presenta. Demuestra estar al día de las discusiones que rodean a la "cuestión lombarda", a la noción de un "arte de los caminos de peregrinación" o al impacto monumental de las ilustraciones de los Beatos, entre otras problemáticas integradas en sus razonamientos sin que estas ahoguen el análisis efectuado. El examen monográfico de Rebordáns y San Martiño no elude el contexto más amplio en el que se insertan, tanto a escala geográfica como en su horizonte cronológico. Esta perspectiva cobra relieve en el cuarto y último bloque del libro, que supone en sí mismo unas conclusiones expandidas bajo el título "Persistencias y reforma". En él se relativiza la movilidad de los obispos promotores como posible factor de adhesión a impulsos reformadores, dado el desdibujado perfil que presentan Gonzalo de Mondoñedo (1077-1108) y Auderico de Tui (1072-c.1100), propuestos como impulsores de los respectivos templos. Las persistencias advertidas en la vigencia de referentes altomedievales o de determinadas devociones, así como la caracterización estilística diversa de lo compostelano, llevan al autor a interrogarse en clave dialéctica sobre la posible intencionalidad de los modelos en un escenario diocesano cambiante: ¿resistencia o reforma? Parece más acertado hablar de pervivencias y continuidades no reñidas con lo novedoso - en las que la formación y competencias de los artífices desempeñarían un papel notable- que de oposiciones. Así, ante el fluctuante espejo de la reforma finisecular, las particularidades de estos templos nos situarían "más ante una muestra de atavismo cultural y no tanto ante una resistencia ideológica consciente".

Como en todo momento de cambio, las creaciones artísticas de estas décadas siguen interpelando a la comunidad investigadora, y las discusiones se antojan lejos de cerrarse. Reflexiones pausadas y balanceadas como las que incluye este libro contribuyen a precisar las preguntas pertinentes y a dibujar mejor los contornos de tan complejas realidades. 